\title{
Incidance, Treatment Options and Outcomes of Stent Loss During Percutaneous Coronary Intervention: A Single-Center Experience
}

\author{
Perkütan Koroner Girişim Sırasında Gelişen Stent Kaybının Sıklığı,
} Demografik Özelliklerinin ve Tedavilerinin Değerlendirilmesi: Tek Merkez Deneyimi

\author{
Yusuf Can, İbrahim Kocayiğit, Muhammed Necati Murat Aksoy \\ ${ }^{1}$ Sakarya University, Department of Cardiology, Sakarya, TURKEY
}

Yazışma Adresi / Correspondence:

Yusuf Can

Korucuk Mahallesi, 2968 ADA Baytur Korukent Sitesi, Orkide:7 Daire:6 Adapazarı/SAKARYA

T: +90541 2514149 E-mail : dr.ycan@hotmail.com

Geliş Tarihi / Received : 03.06.2020 Kabul Tarihi / Accepted : 22.09.2020

Orcid :

Yusuf Can, https://orcid.org/0000-0002-4535-7367

İbrahim Kocayiğit, https://orcid.org/0000-0001-8295-9837

Muhammed Necati Murat Aksoy, https://orcid.org/0000-0002-7722-0330

( Sakarya Tip Dergisi / Sakarya Med J 2020, 10(4):565-571) DoI: 10.31832/smj.747503

\footnotetext{
Abstract

Objective The aim of this study was to evaluate the demographic characteristics, incidence of stent loss, treatment methods and 30-day outcomes of the patients with stent loss during percutaneous coronary intervention (PCI).

Materials Fifteen patients who lost a stent during PCI between December 2014 and February 2020 were included in the study. Outcomes were classified as myocardial infarction, and Methods requirement of bypass revascularization and mortality within 30 days.

Results In our study, the incidence of stent loss during PCI was $0.15 \%$. Of these patients, $12(80 \%)$ were male. The mean age of the patients was $59.87 \pm 8.67$ years. In 3 patients, the stent was deployed at the same location, while in 4 patients, stent crush technique is used. The following retrieval methods were used: inflating the small balloon (\%33.33) and snare (\%20). One patient underwent coronary bypass surgery. One patient died in the hospital. Death, myocardial infarction and requirement of bypass were not observed in the one-month follow-up in the remaining patients. Six patients had type C and 7 patients had type B2 lesions. Eight of the lesions were in left circumflex artery.

Conclusion Coronary stent loss occurs more frequently in the left circumflex artery, and in type B2/C lesions in particular. Interventional cardiologists should know that different treatment methods are available for stent loss in lesions according to the location of the stent, and should be able to successfully treat stent loss in the light of the current data.

Keywords Complication; percutaneous coronary intervention; snare

$\ddot{\mathrm{Oz}}$

Amaç Bu çalıșmanın amacı perkutan koroner girișim sırasında stent kaybı gelișen hastaların demografik özelliklerini, insidansıı, tedavi yöntemlerini ve sonuçlarını değerlendirmektir

Gereç ve Aralı 2014 ve Șubat 2020 tarihleri arasinda perkutan koroner girișim yapılmast strasinda stent kaybı gelișen 15 hasta çalıșmaya dahil edildi. Otuz gün içinde gözlenen miyokard infarktüsü,

Yöntemler baypas ile revaskülarizasyon gereksinimi ve mortalite sonlanim noktaları olarak belirlendi.

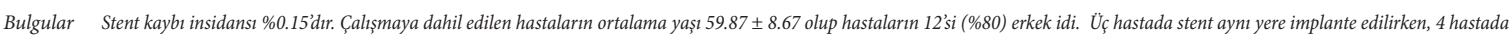
ise farklı bir stent ile ezilerek damara yapıștırldı. Beş hastada küçük balon ile 3 hastada ise kement ile koronerden geri alınmıştır. Bir hastaya koroner arter baypas operasyonu yapıldı. Bir hasta hastanede öldü. Geriye kalan hastalarda 30 günde ölüm, miyokard infarktüsü ve baypas ile revaskülarizasyon gereksinimi gözlenmedi. Altı hastada Tip C, 7 hastada ise Tip B2 lezyon gözlendi. Hastalarin 8 tanesinde stent kaybı sirkumfleks arterdeydi.

Sonuc Koroner stent kaybı tip B2/C lezyonlarını yaninda özellikle sol sirkumfleks arterde daha sık meydana gelmektedir. Girisimsel kardiyologlar stent kaybı durumunda siyrilan stentin bulunduğu yere göre farklı tedavi yöntemleri olduğunu bilmeli ve güncel veriler ıșı̆̆ı̆nda stent kayıplarını bașarılt bir șekilde tedavi edebilmelidir.

Anahtar

Kelimeler Komplikasyon; perkütan koroner girișim; kıska
} 


\section{INTRODUCTION}

Along with the widespread use of percutaneous coronary interventions (PCI) in the last three decades, complications associated with these procedures are also on the rise. Although it is quite rare, one of these complications is stent loss. It can cause severe complications such as myocardial infarction, emergency coronary bypass surgery and mortality. It can also increase morbidity by embolizing the artery that supplies any part of the body, as in cranial embolism. In previous studies, the reported incidence of stent loss was between $0.21 \%$ and $8.4 \%{ }^{1,2}$ Although stent loss was common before the 21st century due to manual handling of the stent, its incidence has decreased in the last two decades. ${ }^{2}$ Here, we aimed to evaluate the incidence, demographic characteristics, treatment methods and 30day outcomes of the patients with stent loss during PCI.

\section{MATERIALS and METHODS}

\section{Study design and population}

This is a single-centred descriptive epidemiological retrospective study which was conducted with patients who lost a stent during PCI between December 2014 and February 2020. Of the 10025 patients who underwent stenting, 15 experienced stent loss. In addition to those that had insufficient angiography records, patients with incomplete clinical follow-up data were excluded. The study was approved by the Sakarya University Faculty of Medicine Ethics Committee (Ethics Committee number:71522473/050.01.04/120).

\section{Study protocol}

Angiographically, lesion characteristics were classified in accordance with the American College of Cardiology (ACC) and American Heart Association (AHA) lesion classifications. ${ }^{3}$ Intracoronary and/or extracoronary embolization was evaluated in patients with stent loss. In patients with stent loss, approaches such as retrieval by snare, medical approaches, the stent crush technique, retrieval by small balloon and implantation of the stent with incremental balloon size were evaluated. Residual stenosis below 30\%, thrombolysis in myocardial infarction 3 flow, dissection, perforation and absence of thrombus were considered successful percutaneous coronary interventions.

\section{Data collection}

Patients' demographic characteristics, clinical characteristics, angiographic characteristics, procedural characteristics, in-hospital and 30-day clinical outcomes (such as myocardial infarction, a revascularization requirement by the bypass, mortality) were retrospectively collected from hospital records, files and angiography records. Moreover, additional information was obtained from the patient and the patient's relatives through the phone calls.

\section{Study Endpoints and Definitions}

Endpoints were myocardial infarction, requirement of bypass revascularization and mortality within 30 days. The diagnosis of myocardial infarction was evaluated according to the fourth universal definition of myocardial infarction guidelines. Coronary procedure-related $\mathrm{MI} \leq 48$ hours after the index procedure was arbitrarily defined as the elevation of cardiac troponin values greater than five times the 99th percentile upper reference limit (URL) in patients with normal baseline values or, in patients with elevated pre-procedure cTn in whom the cTn levels are stable ( $\leq 20 \%$ variation) or falling, the post-procedure $\mathrm{cTn}$ must rise $>20 \%$ to an absolute value more than five times the 99th percentile URL. In addition, one of the following elements is required; (i) Development of new pathological Q waves; (ii) new ischemic ECG changes (iii) Angiographic findings consistent with a procedural flow-limiting complication such as coronary dissection, occlusion of a major epicardial artery or a side branch occlusion/thrombus, disruption of collateral flow, or distal embolization; (iv) imaging evidence of new myocardial loss or regional wall motion abnormalities in a pattern consistent with an ischaemic aetiology were evaluated. ${ }^{4}$ Because patients who presented with acute coronary syndrome were treated with percutaneous coronary intervention at an early stage, PCI-related myocardial infarction could not be distin- 
guished due to baseline troponin values, which were initially high. Therefore, PCI-related myocardial infarction was taken into consideration in the evaluation of patients who underwent percutaneous coronary intervention with stable angina pectoris indication.

\section{Statistical Analysis}

Data were analysed using SPSS 17.0 (SPSS, Inc, Chicago, IL, USA). Compliance of the variables with anormal distribution was determined using the Kolmogorov-Smirnov test. Continuous variables showing a normal distribution were expressed as means and the standard deviation, whereas those with non-normal distributions were expressed using the median (the smallest and greatest values). Categorical data were expressed in percentages. Because there was no control group, a comparative analysis was not performed.

\section{RESULTS}

The mean age of patients with stent loss during percutaneous coronary intervention was $59.87 \pm 8.67$. Of the patients, 12 were male (the demographic characteristics of the patients are shown in Table 1).

\begin{tabular}{|c|c|}
\hline Age, mean $\pm \mathrm{SD}$ (years) & $59.87 \pm 8.67$ \\
\hline Gender(male), n (\%) & $12(80.0)$ \\
\hline Hypertension, n (\%) & $9(60.0)$ \\
\hline Diabetes mellitus, n (\%) & $6(40.0)$ \\
\hline Smoking, $\mathrm{n}(\%)$ & $10(66.66)$ \\
\hline Coronary artery disease, $\mathrm{n}(\%)$ & $4(26.66)$ \\
\hline Perihperal artery disease, $\mathrm{n}(\%)$ & $2(13.33)$ \\
\hline
\end{tabular}

Five of the patients underwent percutaneous coronary intervention with stable angina pectoris indication (the indications are shown in Table 2).

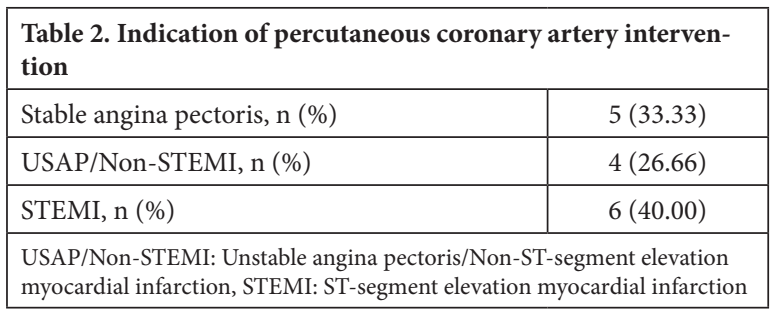

An ACC/AHA Type C lesion was observed in 6 of the patients, and a Type B2 lesion was observed in 7 of the patients. Eight of the lesions were in left circumflex artery. The angiographic characteristics of the patients' lesions are shown in Table 3.

\begin{tabular}{|c|c|}
\hline \multicolumn{2}{|c|}{$\begin{array}{l}\text { Table } 3 \text {. Angiographic characteristics of patients with coronary } \\
\text { stent loss }\end{array}$} \\
\hline \multicolumn{2}{|c|}{ Treated vessel } \\
\hline LAD, n (\%) & $3(20.00)$ \\
\hline LCX, n (\%) & $8(53.33)$ \\
\hline $\mathrm{RCA}, \mathrm{n}(\%)$ & $4(26.66)$ \\
\hline \multicolumn{2}{|l|}{ Lession location } \\
\hline Ostial/proximal, n (\%) & $6(33.33)$ \\
\hline Medial, n (\%) & $8(33.33)$ \\
\hline Distal, n (\%) & $1(6.66)$ \\
\hline \multicolumn{2}{|l|}{ Lession type } \\
\hline $\mathrm{B} 1, \mathrm{n}(\%)$ & $2(13.33)$ \\
\hline $\mathrm{B} 2, \mathrm{n}(\%)$ & $7(46.66)$ \\
\hline $\mathrm{C}, \mathrm{n}(\%)$ & $6(40.00)$ \\
\hline \multicolumn{2}{|c|}{$\begin{array}{l}\text { LAD: Left anterior descending artery, LCX: Left circumflex coronary artery, } \\
\text { RCA: Right coronary artery, American College of Cardiology (ACC) and } \\
\text { American Heart Association (AHA) lesion type: B1, B2, C }\end{array}$} \\
\hline
\end{tabular}

In 7 patients, stent loss was observed with severe lesion calcification, while in 7 other patients, stent loss was observed at the end of the catheter while the stent was retrieved into the catheter. In all 15 patients, the stent was lost in the coronary arteries. In 3 patients, the stent was deployed at the same location with incremental balloon size, while in 4 patients, another stent was implanted at the same location 
that compressed the dislodged stent against the coronary wall. In 5 patients, a small balloon was used to remove and the stent was retrieved by inflating the small balloon. In 3 patients, a lost stent was retrieved with a snare. Of the 8 stents retrieved from the coronary artery, 4 had peripheral embolisms. One of these stents was surgically removed from the femoral artery. One of the stents with a peripheral embolism was in the ulnar artery, and one in the deep femoral artery while another could not be located. Myocardial infarction developed in 3 out of 5 patients who had stent loss as a result of percutaneous intervention with nonacute coronary syndrome. The decision to perform coronary bypass surgery was made for one patient. One patient died in the hospital. Death, myocardial infarction and requirement of bypass were not observed in the one-month follow-up in the remaining patients (Table 4).

\begin{tabular}{|c|c|}
\hline \multicolumn{2}{|c|}{$\begin{array}{l}\text { Table 4. Causes, management and prognosis of patients with } \\
\text { coronary stent loss }\end{array}$} \\
\hline \multicolumn{2}{|l|}{ Causes for stent loss } \\
\hline Unsuccessful retraction into guiding catheter, $\mathrm{n}(\%)$ & $7(46.66)$ \\
\hline Dislodgement in tortuous calcifications, n (\%) & $7(46.66)$ \\
\hline $\begin{array}{l}\text { The first stent implanted in the proximal segment, } \\
\mathrm{n}(\%)\end{array}$ & $1(6.66)$ \\
\hline \multicolumn{2}{|l|}{ Management of intracoronary stent embolization } \\
\hline Successful retrieval into guiding catheter, $\mathrm{n}(\%)$ & $4(26.66)$ \\
\hline Successful intracoronary implantation, n (\%) & $3(20.00)$ \\
\hline Stent crush technique, n (\%) & $4(26.66)$ \\
\hline $\begin{array}{l}\text { Unsuccessful retrieval attempts and extracoronary } \\
\text { embolization, } \mathrm{n}(\%)\end{array}$ & $4(26.66)$ \\
\hline \multicolumn{2}{|l|}{ Management of extracoronary stent embolization } \\
\hline Successful retrieval, n (\%) & $1(6.66)$ \\
\hline Loss in A. femoralis/iliaca/other vessel, n (\%) & $2(13.33)$ \\
\hline Unknown extracoronary location, n (\%) & $1(6.66)$ \\
\hline \multicolumn{2}{|l|}{ Maneuvers of successful stent retrieval } \\
\hline Snare, n (\%) & $3(20.00)$ \\
\hline Small-sized balloon crossing lost stent, $\mathrm{n}(\%)$ & $5(33.33)$ \\
\hline \multicolumn{2}{|l|}{ Outcomes of 30-day } \\
\hline Death, n (\%) & $1(6.66)$ \\
\hline Emergency surgery, n (\%) & $1(6.66)$ \\
\hline Myocardial infarction, n (\%) & $3(20.00)$ \\
\hline
\end{tabular}

\section{DISCUSSION}

The incidence of stent loss, the surgical requirement and the mortality rates in this study were similar to previous studies. Stent loss occurs mostly in the left circumflex artery in Type $2 \mathrm{~B} / \mathrm{C}$ lesions, and we observed that the majority of patients were treated successfully using different methods. ${ }^{5}$

Stent loss can be explained by the following three mechanisms. First, stent loss may occur at the balloon catheter when advancing it to a diseased coronary artery segment. Secondly, a stent may become trapped within the lesion while advancing through the coronary lesion and may detach from the balloon when pulling it back. The third, stent may be trapped in the distal part of the catheter when attempting to retrieve it into the catheter. ${ }^{6}$

Factors affecting stent loss during percutaneous intervention may depend on the patient, the material used or the operator. Among the factors related to the patient, coronary calcification, acute angulation and tortuosity make it difficult for the stent to pass through the coronary artery lesion. ${ }^{5,7,8}$ In the presence of tortuosity and acute angulation, the vessel can be straightened using double wires or stiff wires in order to facilitate the passage of the stent. In the presence of calcification, however, calcified protrusions do not allow the passage of the stent and may cause stent deformation. The factors related to the materials used can be listed as follows. Because poor guide catheter support can reduce the stent's reach to the coronary lesion, stent loss can occur at the balloon while retrieving the stent with the catheter. Stent retrieval may also depend on the structural characteristics of the stents used. It was reported that the incidence of stent loss and embolization with the older generation of paclitaxel-coated stents was greater than in sirolimus-eluting stents and bare metal stents. ${ }^{9,10}$ Although it is not common nowadays, manual handling of the stentalso increases the risk of stent loss. ${ }^{2,11}$ The most important stent loss factor related to the operator is direct stenting, especially without predilating calcified vessels. In addition, 
trying to cross the acute angle and tortuous segment with the stent without using a double wire or stiff wire in the tortuous vessels is another operator-induced factor that can cause stent loss. Implanting the first stent proximally is also among the operator-induced factors. Because stent loss may occur in an attempt to implant a stent distal to the lesion after implanting a stent proximal to the lesion, the stent must be implanted in the distal lesion first. Coaxial insertion of the catheter to prevent the proximal stent from being trapped in the tip of the guide catheter during stent retrieval may reduce the likelihood of stent loss. Accidental inflation of the stent balloon can also cause stent loss. In our patients, about half of the stent loss occurred while retrieving the guide into the catheter, while the other half was due to calcification.

More than half of the stent losses took place during percutaneous interventions performed on the left circumflex artery. This may be particularly related to the lack of coaxial insertion of the catheter as well as the small angle between the circumflex artery and the left main coronary artery.

There is no standard treatment approach for stent loss; it may vary depending on the location of the dislodged stent, the experience of the interventional cardiologist and laboratory materials. In the event of a loss of stent from the balloon, the first goal is to move the stent to a point where it will not cause vital or other serious hazards. If the stent loss occurred in the coronary artery, it should be removed, if possible, or the stent should be placed in a suitable area within the coronary artery. Basically, treatment options can be listed as medical, endovascular and surgical methods. Medical methods are rarely preferred for coronary arteries and are preferred only in cases of embolism in the peripheral arteries except cranial arteries. ${ }^{12,13,14}$ In the case of intracoronary stent loss, methods can be used such as retrieval of the stent using a snare, retrieval of the stent into the catheter by inflating a small-diameter balloon distal to the stent, crushing the stent with a another stent at the same location and compressing the dislodged stent against the coronary wall or a twirling manoeuvre done with a wire inside the stent by passing another wire through the edge of the stent. ${ }^{15,16,17,18} \mathrm{Or}$, if the lost stent cannot be retrieved, it can be implanted in its place if the diameters of the stent and vessel are suitable. The most important thing to note here is whether the stent is on the guide wire. If the lost stent is on the guide wire, different methods can be used. With a snare, a lost stent can be retrieved into the catheter. If the stent diameter is appropriate, a small balloon can be used to recross the lost stent and deploy the stent in situ with incremental balloon size. The stent can be retrieved into the catheter with another small diameter balloon by moving the balloon distal to the stent and then inflating the balloon. Similarly, a second wire is advanced from the edge of the stent and a twirling manoeuvre can be performed with the wire inside the stent to retrieve it into the catheter. If the stent is not on the guide wire, it can be retrieved into the catheter with a snare. Or, the stent can be crushed first with a balloon and then affixed to the wall with a different stent. ${ }^{19}$ In more than half of our patients, the stent was taken out of the coronary artery by retrieval methods. In approximately half of the cases, it was crushed with another stent, and affixed to the vessel wall or implanted in place.

In their meta-analysis, Alomar et al. reported that in 66\% of patients with stent loss, the stent was successfully retrieved from the coronary arteries, $12 \%$ had it implanted in place and $3 \%$ had it crushed and affixed to the vessel wall. ${ }^{2}$ In our study, $53.3 \%$ of lost stents were retrieved from the coronary arteries, $26.6 \%$ were crushed and affixed to the vessel wall and $20 \%$ were implanted in place. In a meta-analysis carried out by Alomar et al., the methods used were $33.7 \%$ snare and $26.1 \%$ balloon retrieval from coronary artery. ${ }^{2}$ In our study, the retrieval methods used were $20 \%$ snare, and $33.33 \%$ balloon retrieval method. The methods of retrieval can vary according to place of stent loss, the facilities of the catheter laboratory and the preference of the physician, so we believe that the rates of use of methods may vary accordingly. 
In addition to the most commonly used snare, retrieval devices such as a basket retrieval device, bile forceps, and an embolism protective device were also used. ${ }^{20,21,22}$ In addition, a lost stent was successfully retrieved with the hairpin wire technique. ${ }^{23}$ We did not use devices other than snares in the catheter lab.

If there is left main coronary disease, left anterior descending artery or multi-vessel disease, the lost stent can be treated surgically if it cannot be retrieved. ${ }^{7,8}$

Brilakis et al. observed 3\% in-hospital mortality, 5\% of patients needing emergency bypass, and $15 \%$ of patients with myocardial infarction. ${ }^{5}$ Bolte et al. also observed that of patients with stent loss, $17.6 \%$ required a coronary bypass, $6.5 \%$ had a myocardial infarction and $6.2 \%$ died. ${ }^{8}$ The low rates of myocardial infarction may be due to diagnoses being made by cardiac troponin (cTnT) creatine kinase $(\mathrm{CK})$, creatine kinase myocardial band (CK-MB) in these studies. Since most of our patients presented with acute coronary syndrome, the rate of development of myocardial infarction is not fully known. In percutaneous coronary interventions with the diagnosis of stable angina pectoris, myocardial infarction was present in 3 out of 5 patients. In our hospital, because diagnoses are made by high-sensitivity cardiac troponin, myocardial infarction may tend to be high. One patient was referred to surgery for a coronary bypass. No 30-day deaths were observed in the hospital, except for one patient who had been treated for acute diffuse anterior myocardial infarction due to cardiogenic shock. In light of these data, the bypass rate was $6.66 \%$ and the mortality rate was $6.66 \%$, similar to previous studies.

\section{Limitations}

The single-centred, retrospective nature of our study and limited number of patients are limitations in this study. In addition, due to the limited number of patients, comparisons between different stents could not be made.

\section{CONCLUSIONS}

Coronary artery stent loss occurs more frequently in the left circumflex artery, and in Type B/C lesions in particular. Interventional cardiologists should know that different treatment methods are available for stent loss in lesions according to the location of the stent, and should be able to successfully treat stent loss in the light of the current data.

The study was approved by the Sakarya University Faculty of Medicine Ethics Committee (Ethics Committee number:71522473/050.01.04/120). 
Sakarya Med J 2020;10(4):565-571

CAN et al., Stent Loss During Percutaneous Coronary Intervention

\section{References}

1. Iturbe JM, Abdel-Karim AR, Papayannis A, Mahmood A, Rangan BV, Banerjee S, et al. Frequency, treatment, and consequences of device loss and entrapment in contemporary percutaneous coronary interventions. J Invasive Cardiol 2012; 24:215-221.

2. Alomar ME, Michael TT, Patel VG, Altomare CG, Rangan BV, Cipher D, et al. Stent loss and retrieval during percutaneous coronary interventions: a systematic review and meta-analysis. J Invasive Cardiol 2013; 25:637-41

3. Ryan TJ, Faxon DP, Gunnar RM, Kennedy JW, King SB 3rd, Loop FD, et al. Guidelines for percutaneous transluminal coronary angioplasty. A report of the American College of Cardiology/American Heart Association Task Force on Assessment of Diagnostic and Therapeutic Cardiovascular Procedures (Subcommittee on Percutaneous Transluminal Coronary Angioplasty). Circulation 1988; 78:486-502.

4. Thygesen K, Alpert JS, Jaffe AS, Chaitman BR, Bax JJ, Morrow DA, et al; ESC Scientific Document Group. Fourth universal definition of myocardial infarction (2018). Eur Heart J 2019; 40:237-269.

5. Brilakis ES, Best PJ, Elesber AA, Barsness GW, Lennon RJ, Holmes DR Jr, et al.Incidence, Retrieval Methods, and Outcomes of Stent Loss During Percutaneous Coronary Intervention: A Large Single-Center Experience. Catheter Cardiovasc Interv 2005; 66:333-40.

6. Brilakis ES, Garratt KN. Device Loss during Percutaneous Coronary Intervention: Incidence, Complications, and Retrieval Methods. In: Ellis SG, Holmes DR Jr, editors. Strategic Approaches in Coronary Intervention. 3rd edition. Philadelphia, USA: Lippincott Williams and Wilkins 2005.p.434-3.

7. Colkesen AY, Baltali M, Acil T, Tekin G, Tekin A, ErolT, et al. Coronary and systemic stent embolizationduring percutaneous coronary interventions: asingle center experience. Int Heart J 2007; 48:129-136.

8. Bolte J, Neumann U, Pfafferott C, Vogt A, Engel HJ, Mehmel HC, et al.Incidence, management, and outcome of stent loss during intracoronary stenting. Am J Cardiol 2001; 88:565-7.

9. Yurtdas M. Aladag N. Yaylali YT. Successful Transcatheter Retrieval of the Embolized Coronary Stent During Primary Percutaneous Coronary Intervention. J Med Cases 2016; 7:417-9.

10. Singh V, Khare R, Chandra S, Dwivedi SK, Saran RK. Dislodgement of a sirolimus - eluting stent in the right coronary artery and its successful deployment with a small-balloon technique. J Indian Coll Cardiol 2014; 4:44-6.

11. Schatz RA, Baim DS, Leon M, Ellis SG, Goldberg S, Hirshfeld JW, et al. Clinical experience with the Palmaz-Schatz coronary stent. Initial results of a multicenter study. Circulation
1991; 83:148-61.

12. Saleh L, Movahed MR. Successful Conservative Treatment of an Undeployed Embolized Intracoronary Stent With Dual Antiplatelet and Warfarin Therapy. Exp Clin Cardiol 2010; 15:e70-2.

13. Kammler J, Leisch F, Kerschner K, Kypta A, Steinwender C, Kratochwill H, et al. Longterm follow up in patients with lost coronary stents during interventional procedures. Am J Cardiol 2006; 98:367-9.

14. Kocayigit I,Can Y, Yllmaz S, Killc H. Undeployed and uncrushed coronary stent in the proximal region of the normal left anterior descending artery revealed four years after intervention.Postepy Kardiol Interwencyjnej 2015; 11:256-257.

15. Kobayashi Y, Nonogi H, Miyazaki S, Daikoku S, Yamamoto Y, Takamiya M. Successful retrieval of unexpanded Palmaz-Schatz stent from left main coronary artery. Cathet Cardiovasc Diagn 1996; 38:402-404.

16. Senturk T, Ozdemir B, Yesilbursa D, Serdar OA. Dislodgement of a sirolimus-eluting stent in the circumflex artery and its successful deployment with a small-balloon technique. Turk Kardiyol Dern Ars 2011; 39:418-421.

17. Yang DH, Woo SI, Kim DH, Park SD, Jang JH, Kwan J, et al. Two dislodged and crushed coronary stents: treatment of two simultaneously dislodged stents using crushing techniques. Korean J Intern Med 2013; 28:718-723.

18. Wong PH. Retrieval of undeployed intracoronary Palmaz-Schatz stents. Cathet Cardiovasc Diagn 1995; 35:218-223.

19. Kwan TW, Chaudhry M, Huang Y, Liou M, Wong S, Zhou X, et al. Approaches for dislodged stent retrieval during transradial percutaneous coronary interventions. Catheter Cardiovasc Interv 2013; 81:245-9.

20. Douard H, Besse P, Broustet JP. Successful retrieval of a lost coronary stent from the descending aorta using a loop basket intravascular retriever set. Cathet Cardiovasc Diagn 1998; 44:224-226.

21. Foster-Smith KW, Garratt KN, Higano ST, Holmes DR Jr. Retrieval techniques for managing flexible intracoronary stent misplacement. Cathet Cardiovasc Diagn 1993; 30:63-68.

22. Khattab AA, Geist V, Toelg R, Richardt G. The AngioGuard: a simplified snare? Int J Cardiovasc Intervent 2004; 6:153-155.

23. Brilakis ES, Abdel-Karim AR, Banerjee S. Hairpin-trap: a novel stent retrieval technique. Catheter Cardiovasc Interv 2011; 77:213-216. 